Мельнікова Ю. І., Клименко І. Ю., Весела М. А.

Національний технічний університет «Дніпровська політехніка», м. Дніпро, Украйна

\title{
ПРОБЛЕМИ РОЗВИТКУ ТРАНСПОРТНОЇ ЛОГІСТИКИ УКРАЇНІ В УМОВАХ ПАНДЕМІЇ
}

\begin{abstract}
Робота присвячена виявленню основних проблем транспортної логістики в галузі автомобільного транспорту. На основі статистичних даних за останні п'ять років був виявлений сталий ріст обсягу перевезень автомобільного транспорту, що доводить його затребуваність на ринку вантажних перевезень України. Виявлено, що сучасні ринкові умови гальмують процес розвитку транспортної логістики. Досліджено основні тенденції в галузі автомобільного транспорту, що спричинені змінами у світовій економіці внаслідок COVID19. Результати проведеного дослідження свідчать, що економічна криза, спровокована пандемією COVID-19, негативно вплинула на всю світову економіку. Автомобільний транспорт відчув негативний вплив коронавірусу. На основі отриманих результатів досліджень окреслені перспективи розвитку ринку транспортної логістики України. Після проведеного аналізу малюється песимістична картина розвитку транспортної галузі, але необхідно відмітити, що попри всі перепони автомобільний транспорт України збільшує обсяги перевезень. Тенденція переваги транспортно-експедиційних компаній, що не мають свого рухомого складу, над іншими транспортними компаніями на вітчизняному ринку ще буде зберігатися тривалий час.

Запропоновано шляхи вирішення виявлених проблем з урахуванням особливостей ринку вантажних перевезень України. Реалізація цих заходів призведе до прискорення доставки вантажу 3 найменшими втратами. Також виявлена обнадійлива перспектива перенесення виробництв європейських компаній з Китаю ближче до ринку збуту дає надію на залучення іноземних інвестиції в економіку України і в транспортну галузь зокрема.

Результати дослідження можуть бути використані менеджерами транспортних компаній при плануванні їх діяльності.

Ключові слова: транспортна логістика, автомобільний транспорт, пандемія, вантажні перевезення, тенденції.
\end{abstract}

\section{ВСТУП}

В сучасних умовах жорсткої конкуренції не залишилось видів діяльності, де недооцінена сфера обігу. Тому застосування принципів логістики, в тому числі і транспортної, формують конкурентні переваги будь-якого підприємства. Найбільший успіх на ринку мають підприємства, що забезпечують своєчасну і якісну доставку продукції до місця призначення. Отже, основною метою транспортної логістики є усунення перебоїв і зайвих витрат при переміщенні транспортних засобів 3 товарами до пункту призначення [1]. Логістика має велике значення як фактор, що формує переваги при виході компанії на ринки. Отже, роль транспорту у веденні бізнесу постійно посилюється, а залучення автомобільного транспорту при побудові ланцюгів постачання набуває все більшої популярності.

\section{АНАЛІЗ ЛІТЕРАТУРНИХ ДАНИХ ТА ПОСТАНОВКА ПРОБЛЕМИ}

Проблеми розвитку транспортної логістики висвітлювались багатьма вченими у своїх роботах: Борисова Л. П. [1], Устенко М. О. [2], Попович П. В. [3], Бойченко М.В. [4], Чухрай Н. І. [5], Лебединська О. I. [6]. На даний момент існує недостатньо досліджень, що висвітлюють вплив пандемії на розвиток транспортної логістики (робота Гірної О.Б. [7]). Непередбачувальний характер впливу наслідків боротьби людства з COVID-19 на соціально-економічне становище світу засвідчує про доцільність продовження дослідження з обраної теми.

\section{ЦІЛЬ ТА ЗАДАЧІ ДОСЛІДЖЕННЯ}

Дослідити стан і тенденції впливу COVID-19 на транспортну логістику в галузі автомобільного транспорту України.

\section{РЕЗУЛЬТАТИ ДОСЛІДЖЕНЬ}

3 кожним роком конкурентна боротьба стає все жорсткішою у всіх сферах діяльності людства. Сучасному вітчизняному ринку притаманні мінливість попиту на транспортні послуги, низький рівень рентабельності, підвищення вимог до якості надаваємих послуг. Кожного дня на ринку відбуваються нові процеси, що формують умови функціонування транспортних компаній. Вплив пандемії, не оминув і галузь автомобільного транспорту.

Розглянемо ситуацію, що склалася на вітчизняному ринку транспортних послуг, а саме динаміку обсягу перевезень за 2016-2020 рр. за всіма видами транспорту (рис. 1). 


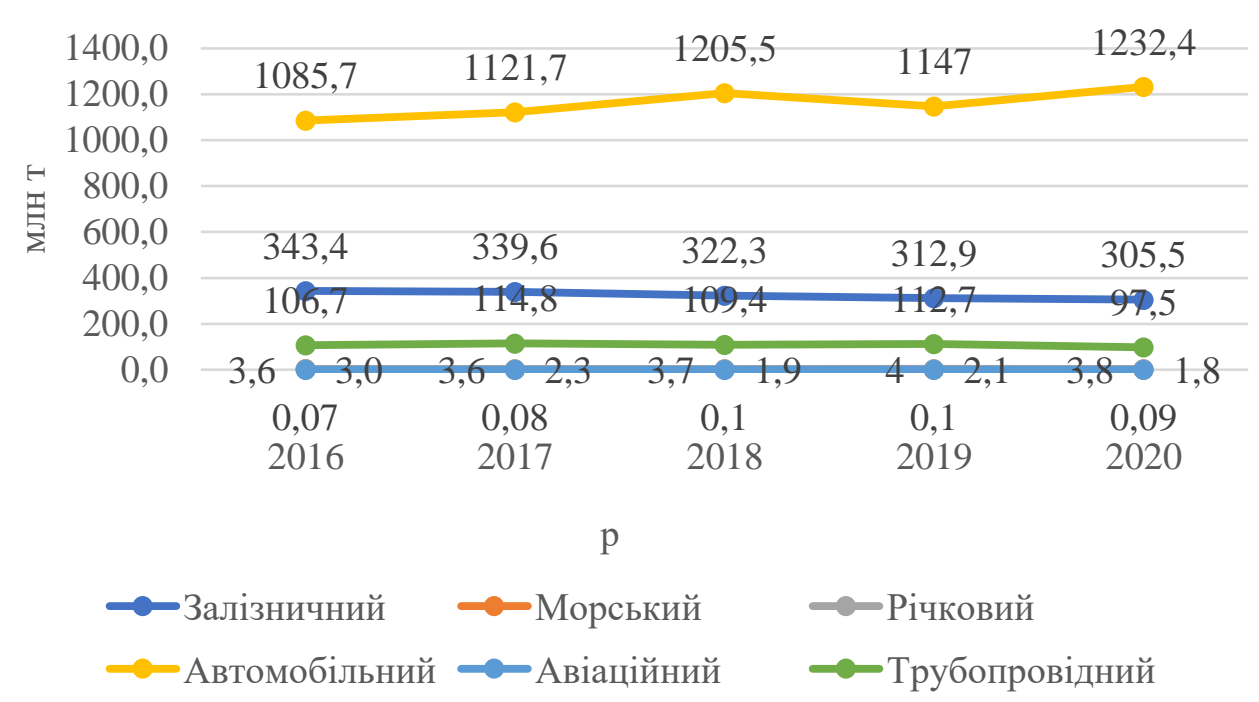

Рисунок 1. Динаміка обсягу перевезень за видами транспорту 2016 - 2020 р. [8]

На основі статистичних даних (рис. 1) за аналізований період можна спостерігати сталий ріст обсягу перевезень автомобільним транспортом, при цьому темп росту складає 113,5\%. 3 одного боку такий темп росту неможна назвати високим, а з іншого - необхідно відмітити, що серйозний економічний шок, спричинений пандемією, який перегукується зі світовою фінансовою кризою 2008p. не призвів до стрімкого скорочення попиту на послуги і понесення значних втрат, як це відбулося у багатьох галузях економіки.

За останні п’ять років спостерігається збільшення долі перевезень автомобільним транспортом (рис. 2), у 2016 р. він складав 70,4\%, а у 2020 р - 75,1\% [8]. Отже, можна з впевненістю стверджувати, що автомобільний транспорт затребуваний на ринку транспортних послуг.

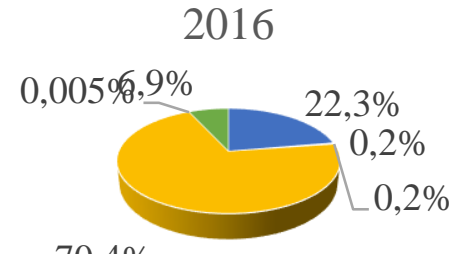

$70,4 \%$

- Залізничний

- Річковий

- Авіаційний

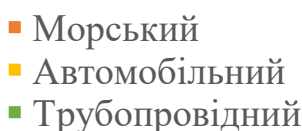

- Залізничний

- Річковий

- Авіаційний
- Морський
- Автомобільний
- Трубопровідний

Рисунок 2 - Порівняння структури обсягу перевезень за видами транспорту 2016 р. 32020 р. [8]

До переваг автомобільного транспорту, що підтверджують доцільність використання саме даного виду транспорту, відносяться: доступність рухомого складу, можливість доставки товару «від дверей до дверей», низькі договірні тарифи через їх демпінгування великою кількістю граків на ринку, висока маневреність і гнучкість, висока швидкість доставки, вибір різноманітних маршрутів $\mathrm{i}$ схем перевезення вантажів, можливість перевезення вантажу різного обсягу.

Отже, виходячи з вищенаведеного, можна відмітити, що автомобільний транспорт є найбільш доступним для споживачів і швидко адаптується до мінливих ринкових умов. Автомобільний транспорт займає вагоме місце в галузі і має непогані перспективи розвитку. Але розвиток автомобільної транспортної логістики України гальмують проблеми, що виникли ще задовго до пандемії. До них можна віднести:

1.Низький рівень розвитку транспортної інфраструктури України, який не відповідає потребам як вітчизняного так і міжнародного ринку. Довгий час якість покриття і невідповідність пропускних спроможностей певних доріг та відсутність об'їзних доріг у деяких містах України були болючою проблемою як для транспортних компаній, так і для громадян. Реалізація національної стратегії «Drive Ukraine 2030» частково покращила ситуацію, але не вирішила проблему. За 2020 р. було 
виконано роботи з будівництва, реконструкції, капітального і поточного ремонту на загальній протяжності 4056 км доріг [9]. Але необхідно відмітити, що певні дороги, що поєднують Україну з країнами ЕС, планують зробити платними. Кабінет Міністрів України затвердив максимальний розмір плати за разовий проїзд дорогою постановою № 1312 від 23.12.2020 р. Цей факт викликає багато питань, на які не можна отримати чіткої відповіді на даний час:

- якої якості будуть альтернативні безкоштовні дороги?

- на яку максимальну вантажопідйомність будуть розраховані платні дороги?

- на скільки раціонально розпоряджається Дорожній фонд коштами, що надходять від платників податків при купівлі палива?

- $\quad$ і т. д.

Незадовільний стан доріг є не єдиною причиною вважати транспортну інфраструктуру України нерозвинутою. Обмежена кількість та низький рівень якості обслуговуючих комплексів придорожнього сервісу, недостатня кількість терміналів, розподільчих центрів досі залишається невирішеним питанням.

Отже, нерозвинута інфраструктура гальмує швидкість доставки вантажу, що знижує конкурентоспроможність вітчизняних транспортних компаній.

1. Високий рівень зносу автомобільного парку України. Розмір, структура та стан рухомого складу характеризує рівень виробничого потенціалу та конкурентоспроможності як автотранспортного підприємства, так і транспортного комплексу країни. Ця проблема стосується всього наземного транспорту України. У 2019 р ступінь зносу основних засобів наземного транспорту склав 59,2\% [8]. Процес оновлення автомобільного парку є дуже болючим питанням, так як від стану рухомого складу залежить безпека та якість перевезень, екологічна безпека та рівень рентабельності перевезень. Отже, на даний час мала доля перевізників може вступати у конкурентну боротьбу 3 перевізниками країн ЄC.

2.Переважна більшість перевізників є представниками малого бізнесу. У 2019 р. тільки 90 млн. т із 1147 млн т вантажу було перевезено автотранспортними підприємствами, отже 92,2\% обсягу перевезень здійснюється фізичними особами-підприємцями [8]. Більшість 3 них мають мінімальні накладні витрати і низький рівень знань щодо формування собівартості перевезень, що призводить до демпінгування тарифів на ринку автомобільних вантажних перевезень. Транспортним компаніям, що мають власний автомобільний парк, майже неможливо досягти високого рівня прибутковості перевезень через дану ситуацію. Тому більшість гравців на українському ринку автомобільних вантажних перевезень є транспортно-експедиційними компаніями, які не мають власного автомобільного парку. Наслідком цього $є$ розрізненість учасників ринку, їх низький рівень конкурентоспроможності, брак коштів для розвитку бізнесу і т. д.

3.Брак кваліфікованої робочої сили в галузі автомобільного транспорту. Автомобільний транспорт $є$ трудомісткою галуззю. Тому проблема дефіциту кваліфікованих трудових ресурсів $\epsilon$ нагальною для транспортних компаній. 3 одного боку на ринку праці спостерігається дефіцит у кваліфікованих і професійних водіях, а з іншого - низький рівень якості управлінського персоналу в сфері автомобільного транспорту. На водіїв покладений високий рівень відповідальності, так як процес перевезення здійснюється поза межами підприємства в умовах підвищеної аварійності.

Також спостерігається брак кваліфікованих логістів. Поєднання сучасних теоретичних знань в логістиці з досвідом практичної діяльності в умовах сьогодення зустрічається на ринку праці дуже рідко. Цей факт негативно вливає на ефективність перевізного процесу.

4. Низький рівень ефективності організації перевізного процесу є результатом негативного впливу проблеми логістичного менеджменту. На багатьох підприємствах досі впровадження логістичних методів полягає у пошуку варіанту доставки вантажу 3 найкоротшою відстанню, що визначається найчастіше логістом на основі власного досвіду, без застосування програмного забезпечення. Мізерна доля транспортних компаній відправляє свій персонал на семінари і курси підвищення кваліфікації, на яких логісти можуть оволодіти сучасними засобами оптимізації перевізного процесу.

5.Низький рівень узгодженості роботи учасників ланцюгів постачання. Непродуктивні простої автомобілів, в першу чергу, викликані невідповідністю пропускної спроможності розподільчих центрів, складів підприємств, митних пунктів пропуску. Практика застосування штрафних санкцій для усунення непродуктивних простоїв на даний момент на вітчизняному ринку $\epsilon$ не дуже розповсюдженою. А простої автомобілів при проходженні митних постів є болючим питанням не тільки для вітчизняних перевізників. Багато транспортних компаній країн ЄС прокладають маршрут, 
оминаючи Україну як транзитну країну, при цьому довжина маршруту може бути значно більша. Закордонні підприємці вважають доцільним доставити швидше вантаж і збільшити матеріальні витрати, ніж скоротити продуктивність автомобіля і збільшити долю амортизації у собівартості перевезень в результаті непродуктивних простоїв.

Попри всі існуючі проблеми в автомобільному транспорті України, позитивним $\epsilon$ те, що попит на вантажні перевезення поступово зростає. Для збереження цієї тенденції необхідно врахувати нові тренди світової економіки, що викликані пандемією короновірусної хвороби.

Пандемія, що зумовлена COVID-19, негативно вплинула на економічну ситуацію у світі. Галузь автомобільного транспорту не залишилась осторонь. Робити довгострокові прогнози дуже важко, бо на сьогодні немає чіткого бачення шляхів подолання вірусу. Але виявити основні тренди, що будуть впливати на розвиток вітчизняної галузі автомобільного транспорту в найближчий час можливо. До таких можна віднести:

1. Вибуття слабких гравців з ринку автомобільних перевезень. Найближчим часом на ринку залишаться тільки ті компанії, які встигнуть переорієнтувати діяльність під мінливі умови, що формує пандемія. В даний час значно легше виживати компаніям, що не мають власного транспорту, бо їх постійні витрати набагато менші ніж у власників автомобільних парків.

2.Перерозподіл вантажопотоків. Зміни викликані об’єктивними процесами, що відбуваються у світі. По-перше, коливання темпів економічного росту. МВФ оцінив світове скорочення ВВП на $3,5 \%$ у 2020 p, у 2021 р - зростання на 5,5\%, а у 2022 р. очікується ріст на 4,2\%[10].

По-друге, зміна поведінки та вподобань споживачів. Пандемія значно вплинула на платоспроможність і поведінку споживачів, що спричинило зміну структури споживчого кошику.

По-третє, істотне подорожчання морського фрахту із Китаю. Удорожчання морського фрахту на $370 \%$ через нестачу контейнерів змушує компанії шукати інші способи доставки товару (зміна маршруту доставки вантажу, виду транспорту) або змінювати постачальників з більш вигідним географічним розташуванням [11].

Всі перелічені обставини безпосередньо впливають на зміну географії вантажовідправників і вантажоотримувачів, періодичність та обсяг доставки. Саме під час пандемії виявився високий рівень залежності виробництв багатьох країн від Китаю. Тому менеджери багатьох компаній розглядають можливість перенесення виробничих потужностей ближче до ринку збуту для скорочення транспортних витрат. Суттєве здороження вартості доставки лишило основної конкурентної переваги морський транспорт і посилило конкурентоспроможність інших видів транспорту. Для доставки вантажу з Китаю все частіше використовують залізничний, авіаційний та автомобільний транспорт.

3. Посилення обмежень діяльності транспортних компаній в країнах ЄС. Особливо болючим питанням ще до пандеміі для перевізників було отримання дозволів на міжнародні вантажні перевезення. Після локдауну 2020 року уряд країн СС посилив захист своїх виробників. Така картина негативно вплинула не тільки на автомобільну галузь, а й на всю економіку країни. Розвиток економіки України в більшій мірі залежить від попиту на експортну продукцію, який в умовах світової кризи падає.

Польща у 2020 році українським перевізникам видала критично мало дозволів на перевезення вантажів автомобільним транспортом у міжнародному сполученні (160 тис. од.). На даний момент постійно ведуться перемови 3 урядами різних країн про отримання додаткових дозволів на міжнародні перевезення. У $2021 \mathrm{p} є$ певні позитивні зміни (Болгарія збільшила кількість дозволів на $25 \%$, Італія - на 6\%) [12], але на стратегічно важливих напрямках, де проходять основні торгівельні потоки, суттєвих зрушень не відбулось.

4.Посилення дефіциту водіїв. Проблема трудової міграції українців обговорювалась на всеукраїнському форумі «Україна 30. Трудові ресурси». Україна є лідером серед європейських країн за кількістю працездатного населення, яке їде працювати за кордон [13]. За даними дослідницької компанії Transport Intelligence, у 2020 році лише у Свропі компаніям, що займаються вантажними перевезеннями, бракувало понад 400 тис. кваліфікованих водіїв [14]. Основні причини трудової міграції водіїв не відрізняються від інших професій: соціальна незахищеність, нестабільний фінансово-економічний стан України, кращі умови праці, більша заробітна плата та перспективи в майбутньому еміграції в країни СС. Значний дефіцит водіїв призведе до зриву ланцюгів постачання, що буде гальмувати відновлення економіки країни.

5.Ріст попиту інвесторів на менш ризикові активи. Інвестиційний клімат України залишається непривабливим. Основними причинами такої ситуації $\epsilon$ нестабільні умови ведення бізнесу, нестабільність у відносинах з іноземними партнерами, податковий тиск, криза, яка спричинена 
короновірусом i т. д. Непередбачувана перспектива економічного розвитку в світі змушує потенційних інвесторів обирати найменш ризикові варіанти, до яких галузь автомобільних перевезень не відноситься.

1.Поява нової вимоги споживачів до транспортних компаній - можливість зробити онлайн заявку на здійснення перевезення вантажу. Керівництво транспортних компаній розуміє необхідність даної опції в умовах пандемії, тому більшість компаній вже ії мають.

\section{ОБГОВОРЕННЯ РЕЗУЛЬТАТІВ ДОСЛІДЖЕННЯ}

Для успішного пристосування до похитних ринкових умов сьогодення керівництву транспортних компаній при здійсненні управлінської діяльності необхідно враховувати тенденції, що зумовлені COVID-19. Тому основною метою менеджерів $є$ успішне подолання безлічі труднощів. Цей шлях можна пройти за допомогою:

- підвищення рівня сервісу за рахунок гнучкості в обслуговуванні;

- застосування різноманітних способів доставки вантажу ( перевезення збірних вантажів, змішані перевезення і т. д.);

- автоматизації процесу оптимізації вантажних перевезень.

Необхідно відмітити, що втілити запропоновані заходи не так легко.

Високий рівень гнучкості в обслуговуванні в сучасних українських реаліях найлегше досягти, використовуючи найманий рухомий склад будь-якого типу і вантажопідйомності. Тому тенденція верховенства компаній, які не мають власного автомобільного парку, на вітчизняному ринку ще буде зберігатися. Цей варіант позволяє значно скоротити постійні витрати компанії, але якість надаваємих послуг залежить від власника рухомого складу. Однак необхідно відмітити, що кожна компанія має список недобросовісних перевізників, з якими воліє не вступати у ділові відносини.

Втілення перевезення збірних вантажів і автоматизації процесу оптимізації вантажних перевезень гальмують дві основних проблеми: брак інвестицій і дефіцит кваліфікованих логістів.

Доцільність застосування програмного забезпечення для вибору оптимального маршруту доставки та використання розподільчих центрів при певних маршрутах $є$ безперечною, але для їх застосування необхідні чималі гроші. Так як переважна більшість граків на ринку є представниками малого бізнесу, то брак коштів не дозволяє реалізувати запропоновані заходи. В умовах економічної кризи знайти інвесторів є майже нездійсненою задачею.

Керівництву транспортних компаній необхідно приділити велику увагу підвищенню професіоналізму і розвитку «логістичної інтуїції» персоналу. Логіст повинен прогнозувати зміни попиту на транспортні послуги при виборі маршруту і виду транспорту, враховувати вимоги клієнта, інтенсивність руху транспортних коридорів, тривалість проведення певних операцій, кліматичні умови та ін. Отже, при побудові ланцюгу постачань людський фактор грає велике значення.

\section{ВИСНОВКИ}

В результаті аналізу малюється песимістична картина розвитку транспортної галузі в Україні, але необхідно відмітити, що попри всі перепони автомобільний транспорт України збільшує обсяги перевезень. У першому півріччі 2021 р. (78,2 млн. т.) було перевезено вантажу на 21,4\% більше ніж за аналогічний період 2020 р. (64,4 млн. т) [8]. Перспектива перенесення виробництв європейських компаній з Китаю ближче до ринку збуту дає надію на залучення іноземних інвестиції в економіку України і в транспортну галузь зокрема.

Отже, підвищення стійкості транспортних компаній можна забезпечити за допомогою високого рівня сервісу, застосування різних способів доставки вантажів, автоматизації процесу побудови ланцюгів постачань, підвищення професіоналізму персоналу, що призведе до прискорення доставки вантажу з найменшими втратами.

\section{ПЕРЕЛІК ДЖЕРЕЛ ПОСИЛАННЯ}

1. Борисова Л. П. Основные проблемы и перспективы развития транспортной логистики в Украине / Л. П. Борисова. // Економіка. Управління. Інновації. Серія : Економічні науки. - 2013. - № 2. - Режим доступу: http://nbuv.gov.ua/UJRN/eui_2013_2_13

2. Устенко М. О. Основні напрямки розвитку та завдання транспортної логістики / М. О. Устенко // Вісник економіки транспорту і промисловості. - 2018. - № 62. - С. 138-144.

3. Попович П. В. Дослідження тенденцій розвитку ринку вантажних автомобільних перевезень у сучасних умовах / П. В. Попович, О. С. Шевчук, А. Й. Матвіїшин, В. М. Лотоцька // Вісник Житомирського державного технологічного університету. Серія : Технічні науки. - 2016. - № 2. - С. 224-229. 
4. М.В. Бойченко Проблеми транспортної логістики вантажних перевезень в Україні / М.В. Бойченко // Вісник економічної науки України. — 2018. — № 2 (35). — С. 22-26.

5. Чухрай Н. І. Оцінювання функціонування ланцюга поставок: сутність та концептуальні підходи / Н. І. Чухрай // Вісн. Нац. ун-ту "Львів. політехніка". - 2009. - № 647. - С. 276-285.

6. Лебединська О.І. Особливості міжнародної логістики в умовах глобалізації. Вісник ХНАУ. Серія «Економічні науки». 2017. № 3. С. 195-201

7. Гірна О.Б., Кобилюх О.Я. Реалії та перспективи пандемії COVID-19 для транспортної логістики. Науковий журнал «Молодий вчений». 2020. №7 (83) липень. С. 208-214.

8. Державний комітет статистики України [Електрон. ресурс]. - Режим доступу: http://www.ukrstat.gov.ua/operativ/menu/menu_u/tr.htm Режим

9. Звіт Державного агентства автомобільних доріг України за 2020 р. [Електрон. ресурс]. https://ukravtodor.gov.ua/press/news/publichnyi zvit holovy derzhavnoho ahentstva avtomobilnykh dorih _ukrainy_oleksandra_kubrakova_za_2020_rik_video/zvit_pro_diialnist_derzhavnoho_ahentstva_avtomobiln ykh dorih ukrainy za 2020 rik.pdf

10. МВФ: Світовий ВВП у 2020 році впав на 3,5\%, у 2021 році зросте на 5,5\%. [Електрон. pecypc]. - Режим доступу: https://finbalance.com.ua/news/mvf-polipshiv-prohnoz-zrostannya-svitovoekonomiki-v-2021-rotsi-do-55

11. Чому злетіли ціни на морські перевезення та як це позначиться на Україні. [Електрон. pecypc]. - Режим доступу: https://www.epravda.com.ua/publications/2021/08/30/677292/

12. Міністерство інфраструктури України. [Електрон. ресурс]. - Режим доступу: https://mtu.gov.ua/news/32958.html

13. Трудова міграція українців - як запобігти відтоку людей, обговорюють на "Україна 30". [Електрон. ресурс]. - Режим доступу: https://kanaldom.tv/uk/trudovaya-migracziya-ukrainczev-kakpredotvratit-ottok-lyudej-obsuzhdayut-na-ukraina-30-video/

14. У світі не вистачає далекобійників: куди поділися водії та які країни заманюють українців на роботу. доступу:https://www.epravda.com.ua/publications/2021/09/17/677904/

\section{REFERENCES}

1.Borisova L. P. Osnovnye problemy i perspektivy razvitiya transportnoj logistiki v Ukraine / L. P. Borisova. // Ekonomika. Upravlinnya. Innovaciï. Seriya : Ekonomichni nauki. - 2013. - № 2. - Rezhim dostupu: http://nbuv.gov.ua/UJRN/eui $2013 \quad 2 \quad 13$

2. Ustenko M. O. Osnovni napriamky rozvytku ta zavdannia transportnoi lohistyky / M. O. Ustenko // Visnyk ekonomiky transportu i promyslovosti. - 2018. - № 62. - S. 138-144.

3. Popovych P. V. Doslidzhennia tendentsii rozvytku rynku vantazhnykh avtomobilnykh perevezen u suchasnykh umovakh / P. V. Popovych, O. S. Shevchuk, A. Y. Matviishyn, V. M. Lototska // Visnyk Zhytomyrskoho derzhavnoho tekhnolohichnoho universytetu. Seriia : Tekhnichni nauky. - 2016. - № 2. - S. 224-229.

4. M.V. Boichenko Problemy transportnoi lohistyky vantazhnykh perevezen v Ukraini / M.V. Boichenko // Visnyk ekonomichnoi nauky Ukrainy. — 2018. — № 2 (35). — S. 22-26.

5. Chukhrai N. I. Otsiniuvannia funktsionuvannia lantsiuha postavok: sutnist ta kontseptualni pidkhody / N. I. Chukhrai // Visn. Nats. un-tu "Lviv. politekhnika". - 2009. - № 647. - S. 276-285.

6. Lebedynska O.I. Osoblyvosti mizhnarodnoi lohistyky v umovakh hlobalizatsii. Visnyk KhNAU. Seriia «Ekonomichni nauky». 2017. № 3. S. 195-201

7. Гірна О.Б., Кобилюх О.Я. Реалії та перспективи пандемії COVID-19 для транспортної логістики. Науковий журнал «Молодий вчений». 2020. №7 (83) липень. С. 208-214.

8. Derzhavnyi komitet statystyky Ukrainy [Elektron. resurs]. - Rezhym dostupu: http://www.ukrstat.gov.ua/operativ/menu/menu_u/tr.htm

9. Zvit Derzhavnoho ahentstva avtomobilnykh dorih Ukrainy za 2020 r. [Elektron. resurs]. - Rezhym dostupu:

https://ukravtodor.gov.ua/press/news/publichnyi_zvit_holovy_derzhavnoho_ahentstva_avtomobilnykh_dorih _ukrainy_oleksandra_kubrakova_za_2020_rik_video/zvit_pro_diialnist_derzhavnoho_ahentstva_avtomobiln ykh_dorih_ukrainy_za_2020_rik.pdf 
10. MVF: Svitovyi VVP u 2020 rotsi vpav na 3,5\%, u 2021 rotsi zroste na 5,5\%. [Elektron. resurs]. Rezhym dostupu: https://finbalance.com.ua/news/mvf-polipshiv-prohnoz-zrostannya-svitovo-ekonomiki-v2021-rotsi-do-55

11. Chomu zletily tsiny na morski perevezennia ta yak tse poznachytsia na Ukraini. [Elektron. resurs]. - Rezhym dostupu: https://www.epravda.com.ua/publications/2021/08/30/677292/

12. Ministerstvo infrastruktury Ukrainy. [Elektron. resurs]. - Rezhym dostupu: https://mtu.gov.ua/news/32958.html

13. Trudova mihratsiia ukraintsiv - yak zapobihty vidtoku liudei, obhovoriuiut na "Ukraina 30". [Elektron. resurs]. - Rezhym dostupu: https://kanaldom.tv/uk/trudovaya-migracziya-ukrainczev-kakpredotvratit-ottok-lyudej-obsuzhdayut-na-ukraina-30-video/

14. U sviti ne vystachaie dalekobiinykiv: kudy podilysia vodii ta yaki krainy zamaniuiut ukraintsiv na robotu. [Elektron. resurs]. - Rezhym dostupu:https://www.epravda.com.ua/publications/2021/09/17/677904/

Y. Melnikova, I. Klymenko, M. Vesela. Problems of the development of transport logistics of Ukraine in terms of pandemic

The study deals with the identification of key problems of transport logistics in the field of motor transport. The statistic data for the recent five years have helped to specify sustainable growth in the motor transportation; it proves that the motor transport is in demand on the cargo transportation market of Ukraine. It has been defined that current market conditions decelerates the process of transportation logistics development. Basic tendencies in the field of motor transport, caused by the changes in world economy due to COVID-19, have been analyzed. The research results show that the economic crisis provoked by COVID19 pandemic has influences negatively the worldwide economy on the whole. In particular, motor transport has experienced negative impact of the coronavirus. The obtained results have made it possible to outline the prospects of further development of the Ukrainian transport logistics market. The carried out analysis has demonstrated a pessimistic pattern of the transport logistics development; however, it should be noted that despite all the obstacles, Ukrainian motor transport is increasing its transportation volumes. There will be still a long-time tendency of certain advantage of transportation-dispatch companies, having no own motor equipment, over other transportation companies on the national market.

Certain methods to solve the identified problems have been proposed taking into consideration features of the cargo transportation market. Implementation of those methods will result in the accelerated cargo delivery with the least costs. Moreover, the encouraging prospects as for the transfer of production facilities of European countries from China closer to the market outlets bring certain hope for the involvement of foreign investment in the Ukrainian economy in general and transportation field in particular.

The research results can be used by managers of transportation companies while planning the enterprise activities.

Key words: transport logistics, road transport, pandemic, freight transportation, trends.

МЕЛЬНІКОВА Юлія Ігорівна, старший викладач кафедри «Управління на транспорті», Національний технічний університет «Дніпровська політехніка», e-mail: yulaskripa@gmail.com, https://orcid.org/0000-0001-7023-023X

КЛИМЕНКО Ірина Юрї̈вна, кандидат технічних наук, доцент кафедри «Управління на транспорті», Національний технічний університет «Дніпровська політехніка», e-mail: klymenkoiy@gmail.com, https://orcid.org/0000-0002-6263-0951

BECEЛА Марія Анатоліїна, кандидат технічних наук, доцент кафедри «Управління на транспорті», Національний технічний університет «Дніпровська політехніка», e-mail: mves357@gmail.com, http://orcid.org/0000-0001-9318-9110

Yuliia MELNIKOVA, Senior Lecturer of Transport Management Department, Dnipro University of Technology, e-mail: yulaskripa@gmail.com, https://orcid.org/0000-0001-7023-023X

Iryna KLYMENKO, Candidate of Technical Science, associate professor of Transport Management Department, Dnipro University of Technology, e-mail: klymenkoiy@gmail.com, https://orcid.org/0000-0002$\underline{6263-0951}$

Mariia VESELA, Candidate of Technical Science, associate professor of Transport Management Department, Dnipro University of Technology, e-mail: mves357@gmail.com, http://orcid.org/0000-0001-93189110

DOI 10.36910/automash.v2i17.640 